\title{
Fallback Methods as a Basis of Customs Valuation on Imported Goods: Reality Facing Rules and Laws
}

\author{
Teuta Balliu \\ PhD Candidate, Finance lecturer at Economic Faculty, \\ University “A.Xhuvani”, Elbasan, Albania \\ Aida Gaçe (LLozana) \\ PhD Candidate, Law lecturer at Economic Faculty, \\ University "A.Xhuvani”, Elbasan, Albania
}

Doi:10.5901/mjss.2014.v5n4p174

\begin{abstract}
The accomplishment of customs plan of incomes as a form of public revenues is among the main goals of the customs administration. This goal is realized under certain norms and rules. Our focus is on the practice of custom valuation of imported goods. In other words how are methods applied in valuating goods for customs purpose? Initially we are focused on the concepts of customs valuation, customs value, and the methods on which this process is realized. What strikes since the beginning is that the legal base under which the customs administration operates is commensurate to the norms and rules of international institutions. Further you will find complete information about the reference value as one of the valuation methods which is used to asses most of imported goods. If we refer to the law we can say that customs valuation methods are long and they have a hierarchical nature, so initially we judge on the possibility of applying the method that we listed earlier. If we refer to the practice we can clearly distinguish the tendency of customs officers to apply reference values, known differently as references in the process of customs valuation. Perhaps in this way the main goal of customs administration is realized, which is the harvesting of as much incomes as possible, but not what is widely rumored lately the business partnership and positive climate of doing business.
\end{abstract}

Keywords: customs valuation, customs value, fallback method.

\section{Introduction}

Demography, investment, technology, energy and other natural resources, transportation costs and institutions are fundamental economic factors that shape the overall nature of trade and explain why countries trade (WTO, Trade Raport, 2013, p. 7). What we mean with institutions? Institutions include social norms, ordinary laws, regulations, political constitutions and international treaties within which policies are determined and economic exchanges are structured. In this context we understand that the consolidated institutions stimulate the international integration and are considered as an important recourse for competitive advantages. Being successful on our days when the main objective is survival requires institutions that protect property rights, ensure fair play, protect rules and legal norms and ensure impartiality and equal treatment. All these taken together in the business view are translated as lower costs and less risks. Nobody and nothing can overshadow the importance of the relationships and the strong connection between financial costs of the business and reliable and unbiased institutions. By saying this it is understood that the importance of these institutions, especially those financial ones also effects international trade. Companies constantly strive to develop strategies that would improve cash flows in order to enrich their stocks. Recently many of the barriers of entering foreign markets are reduced or completely eliminated encouraging in this way the companies to become part of the international market. At first companies may try to export their products to a particular country or to import goods from a foreign producer. However, this path is indisputably paved and fixed time after time by laws which already go beyond the national. What we aim to see and analyze in this article is a part of this road. Through it we want to focus on customs valuation of imported goods.

\section{Custom Valuation}


The purpose of customs valuation for goods can be seen in two perspectives, that fiscal and economic. Therefore seen on the fiscal perspective we can say that the levels of the duties and the tariffs are generally expressed as \% (percentage) on the customs value of goods. This way we have a taxation system "ad valorem". On the other hand we all know that taxes are the main source of public revenues collection (WCO, Revenue Management Conference, December 2009 , p. 3) with which the state fulfills the public expenditures under its competence. The fourth president of the United States James Madison stated that:

"The power of taxing people and their property is essential to the very existence of government."

In the ancient state tax concept is explained as something given to from the submission people to the other people, and as such tax was identified as submission (Ashiku, 2010, p. 17). In various literatures you find it expressed clearly that a state has to three ways to provide the needed money for financing public expenditures a) to emit money, $b$ ) collect taxes, c) borrowing (Rosen\&Gayer, 2010, p. 25). But on what basis are taxes collected? Customs valuation is a process through which the Albanian customs administration determines customs values of imported goods and further applying tax rates. Naturally the question whether we are consistent with the international practices legislation comes into our minds. Albania joined the World Trade Organization (WTO) on 8th September 2000 and as such it is obliged to implement Article VII of the "General Agreement on tariffs and trade" (GATT), 1994. Although Albania's membership was made one year after the entry into force of the Albanian Customs Code ${ }^{1}$, the valuation methodology of goods for customs reasons is in full compliance with Article VII of GATT.

Let us first explain the concepts with which this paper relates.

The custom valuation is a custom procedure applied to determine the customs value of imported goods. If the rate of duty is ad valorem, the customs value is essential to determine the duty to be paid on an imported good.

"The customs value of imported goods shall be the transaction value, that is, the price actually paid or payable for the goods when sold for export to the customs territory of the Community, adjusted, where necessary, in accordance with Articles 32 and 33" (WCO, 2007, pp. 23-24).

The customs value is used as the basis for calculating customs duties. It is a composition of cost, insurance, freight of goods imported through road or rail and cost of goods imported through air.

The customs value definition has its own history. The value for customs purposes of imported merchandise should be based on the actual value of the imported merchandise on which duty is assessed, or of like merchandise, and should not be based on the value of merchandise of national origin or on arbitrary or fictitious values (WTO, General Agreements on Tariffs and Trade, 1994, p. 13). Starting in the 1950s, customs duties were assessed by many countries according to the Brussels Definition of Value. Under this method, a normal market price, defined as "the price that a good would fetch in an open market between a buyer and seller independent of each other," was determined for each product, according to which the duty was assessed. This method caused widespread dissatisfaction among traders, as price changes and competitive advantages of firms were not reflected until the notional price was adjusted by the customs office after certain periods of time. New and rare products were often not captured in the lists, which made determination of the "normal price" difficult. It was clear that a more flexible and uniform valuation method was needed which would harmonize the systems of all countries. Going on The Tokyo Round Valuation Code, or the Agreement on Implementation of Article VII of the GATT, concluded in 1979, established a positive system of Customs Valuation based on the price actually paid or payable for the imported goods. Based on the "transaction value", it was intended to provide a fair, uniform and neutral system for the valuation of goods for customs purposes, conforming to commercial realities. This Code was replaced by the WTO Agreement on Implementation of Article VII of the GATT 1994. This Agreement applies only to the valuation of imported goods for the purpose of levying ad valorem duties on such goods. It does not contain obligations concerning valuation for purposes of determining export duties or quota administration based on the value of goods, nor does it lay down conditions for the valuation of goods for internal taxation or foreign exchange control.

There are six methods of goods valuation for customs purpose according to the Customs Code of the Republic of Albania, which as we pointed out above is in full compliance with Article VII of GATT:

- Method 1: transaction value

- Method 2: value of identical goods

- Method 3: value of similar goods

${ }^{1}$ Law 8449 date 21.01.1999 
- Method 4: equivalent selling price in EU

- Method 5: (interchangeable with method 4) cost of production of goods

- Method 6: fallback

Let's go back again to the main focus of this paper.

What can we say abort the sixth evaluation method? Regarding this evaluation methods we can say that when the customs value cannot be determined under any of the first five methods, it may be determined using reasonable means consistent with the principles and general provisions of the Agreement and of Article VII of GATT, and on the basis of data available in the country of importation. To the greatest extent possible, this method should be based on previously determined values and methods with a reasonable degree of flexibility in their application.

Valuation criteria not to be used (WTO, General Agreements on Tariffs and Trade, 1994, p. 23):

Under the fall-back method, the customs value must not be based on:

- The selling price of goods in the country of importation (i.e. the sale price of goods manufactured in the importing country);

- A system which provides for the acceptance for customs purposes of the higher of two alternative values (the lowest should be used);

- The price of goods on the domestic market of the country of exportation (valuation on this basis would go against the principle in the Preamble that "valuation procedures should not be used to combat dumping");

- The cost of production other than computed values which have been determined for identical or similar goods (valuation must be arrived at on the basis of data available in the country of importation);

- The price of goods for export to a third country (two export markets are always to be treated as separate and the price to one should not control the customs value in the other);

- Minimum customs value (unless a developing country has taken the exception which allows for use of minimum values);

- Arbitrary or fictitious values (these prohibitions are aimed at systems which do not base their values on what happens in fact in the marketplace, as reflected in actual prices, in actual sales, and in actual costs, reason of the importation or sale of the goods are also to be deducted.

\section{Customs Valuation Practices}

The WTO Customs Valuation Agreement is based on a "positive" as opposed to a "normative" economic principle: what the value of the goods is, rather than what the value of the goods should be, is taken as the correct customs value. Thus, the Agreement's primary basis of valuation is "transaction value" which is "the price actually paid or payable" by the buyer for the imported goods (WTO, A Handbook on WTO Customs Valuation Agreemnts, 2010, p. 22). In this paper we are focused on the use of method $\mathrm{nr}$ six by the Albanian Customs Administration for evaluating the imports. This method is not used much in the European practices According the WCO today, more than $90 \%$ of world trade is valued on the basis of the transaction value method which provides more predictability, uniformity and transparency for the business community (WCO, What is customs valuation, 2013).

Which is the Albanian actuality? Where are we on the way towards integration and adaption to the international practices and reality? How prepared are we for them, facing the demands and business needs?

In order to have a clearer picture we have elaborated the customs declarations for the period SeptemberNovember 2013 at the Department of Customs Elbasan for the product fabric with nomenclature code 5407 imported from different countries (GDC, 2013)2. As shown on table 2, 79\% of the total imports or declarations of 115 fabric article originally Turkish were evaluated according to the first method of assessment, that of the purchase invoice. While in the assessment of $15 \%$ of them reference or data from this institution are used. The situation is almost the same even if we refer to the method use for valuating Italian fabrics. The evaluation of Chinese goods overturns the situation, this because the customs administration representatives structures in $60 \%$ of customs practices have used references as a basis for the assessment of imported fabrics. The data are very different if we refer to China as the country of origin, this also for the difficulties of checking their bills or even for the risk carried in these cases. Generally bills of the Chinese goods are considered as the riskiest.

${ }^{2}$ According to the combined nomeclature of goods for 2013 of the General Department of Customs goods code 5407 include "Woven fabrics of synthetic filament yarns" $p 320$ 
Table 2: Methods of Customs Valuation practiced for fabric article.

\begin{tabular}{|c|c|c|c|c|c|c|c|}
\hline \multirow[b]{2}{*}{ Origin } & \multicolumn{6}{|c|}{ Valuation Methods } & \multirow{2}{*}{ Total Declaration } \\
\hline & 1 & 2 & 3 & 4 & 5 & 6 & \\
\hline Turkey & $79 \%$ & $0 \%$ & $0 \%$ & $0 \%$ & $6 \%$ & $15 \%$ & 115 \\
\hline China & $33 \%$ & $0 \%$ & $0 \%$ & $0 \%$ & $7 \%$ & $60 \%$ & 45 \\
\hline Italy & $76 \%$ & $0 \%$ & $0 \%$ & $0 \%$ & $0 \%$ & $24 \%$ & 37 \\
\hline Greece & $50 \%$ & $0 \%$ & $0 \%$ & $0 \%$ & $0 \%$ & $50 \%$ & 4 \\
\hline Spain & $100 \%$ & $0 \%$ & $0 \%$ & $0 \%$ & $0 \%$ & $0 \%$ & 14 \\
\hline Syria & $100 \%$ & $0 \%$ & $0 \%$ & $0 \%$ & $0 \%$ & $0 \%$ & 2 \\
\hline$A E$ & $0 \%$ & $0 \%$ & $0 \%$ & $0 \%$ & $0 \%$ & $100 \%$ & 2 \\
\hline
\end{tabular}

What we have noticed along the processing of these data is the fact that the other four methods (methods 2-5) are almost never used. While the methods of customs valuation have a hierarchical nature, so initially it is judged on the possibility of using the method which is first ranked and then at the end we can pass or apply the sixth method or the socalled reference. All this implies the tendency of customs officers to apply the reference in the valuation process realizing in this way the main objective of the customs administration that of collecting as much revenue as possible.

How would the customs revenue change if we would accept the value of the invoice as the basis of the customs valuation for all the imports taken in the analysis? In table number 3 you will find the statistical value obtained according to the three methods of evaluation, practically applied in the last column of the collected customs revenue. It should be noted that the customs duty on the product is zero ${ }^{3}$. In total for this quarter it is harvested 58259518 ALL custom revenues from imported fabrics.

Table 3: Statistical value according to the methods of evaluation practiced for the period September - November 2013 for the fabric product with nomenclature number 5407 in Elbasan Customs Branch.

\begin{tabular}{|l|r|r|r|r|r|r|r|}
\hline Origin & $\begin{array}{l}\text { Customs valuation } \\
\text { With 1st method }\end{array}$ & $\begin{array}{l}\text { Customs valuation } \\
\text { with } 5^{\text {th }} \text { method }\end{array}$ & $\begin{array}{l}\text { Custom valuation } \\
\text { With } 6^{\text {th }} \text { method }\end{array}$ & $\begin{array}{r}\text { Total Statistical } \\
\text { Value }\end{array}$ & TD & VAT & $\begin{array}{l}\text { The real customs } \\
\text { revenue }\end{array}$ \\
\hline Turkey & $77,643,472$ & $6,676,485$ & $5,854,016$ & $90,173,973$ & $0 \%$ & $20 \%$ & $18,034,795$ \\
\hline China & $39,466,180$ & $10,114,036$ & $92,967,426$ & $142,547,642$ & $0 \%$ & $20 \%$ & $28,509,528$ \\
\hline Italy & $3,745,173$ & - & $22,067,238$ & $31,812,411$ & $0 \%$ & $20 \%$ & $6,362,482$ \\
\hline Greece & 156,285 & - & 522,402 & 678,687 & $0 \%$ & $20 \%$ & 135,737 \\
\hline Spain & $6,846,612$ & - & - & $6,846,612$ & $0 \%$ & $20 \%$ & $1,369,322$ \\
\hline Syria & $7,449,686$ & - & - & $7,449,686$ & $0 \%$ & $20 \%$ & $1,489,937$ \\
\hline AE & - & - & $11,788,581$ & $11,788,581$ & $0 \%$ & $20 \%$ & $2,357,716$ \\
\hline TOTAL & $\mathbf{1 3 5 , 3 0 7 , 4 0 8}$ & $\mathbf{1 6 , 7 9 0 , 5 2 1}$ & $\mathbf{1 3 3 , 1 9 9 , 6 6 3}$ & $\mathbf{2 9 1 , 2 9 7 , 5 9 2}$ & $\mathbf{0} \%$ & $\mathbf{2 0} \%$ & $\mathbf{5 8 , 2 5 9 , 5 1 8}$ \\
\hline
\end{tabular}

No doubt that the situation would be different if we assumed that for all these imports we would use the transaction method, differently said accepting the invoice value. In table number 4 and more specifically in columns 3 and 4 based on the coefficient of the intervention for each import we have converted the statistical value obtained by applying methods number 5 and 6 for the customs valuation in statistical value according to the transaction value. So for instance, the statistical value after applying method number 6 of customs valuation to one of the imports of Turkish origin is $894,016.5 \mathrm{ALL}$ and for that the evaluation coefficient is 1.3. If we put this statistical value into the report with its coefficient we would gain the statistical value based on the value of the transaction. This calculation is done separately for each import.

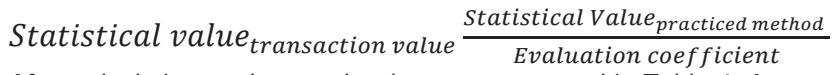

After calculating each case the data are presented in Table 4. As you can see the total of customs revenue would be 9,951,396 ALL lower. Referring to imports from European countries, where the possibility of verifying the origin of the financial is high as a result that our state has agreements with these states. Thus referring to imports from our

${ }^{3}$ According to the combined nomenclature of goods for 2013 of the General Department of Customs duty rate for goods with code 5407 is $0 \%, p 320$ 
neighboring state Italy we have collected customs revenue of 3,835,317 ALL higher. In these cases the business costs and consequences are known because the application of the same tax on a grater customs value brings a price increase in the imported goods (when other factors remain unchanged). Much of the business cash flows come from payments of purchased products or the receipts payment for the products that it sells or exports in the internal market.

Table 4: The hypothetic statistical value for the period September - November 2013 for the fabric product with nomenclature number 5407 in Elbasan Customs Branch, and the difference in the customs revenue.

\begin{tabular}{|l|r|l|l|r|r|r|r|r|r|}
\hline Origins & $\begin{array}{l}\text { Customs valuation } \\
\text { lst method }\end{array}$ & $\begin{array}{l}\text { Customs valuation } \\
\text { th method } \\
\text { converted lst }\end{array}$ & $\begin{array}{l}\text { Customs valuation } \\
\text { 6th method } \\
\text { converted 1st }\end{array}$ & $\begin{array}{l}\text { Hypothetic } \\
\text { Statistical Value }\end{array}$ & TD & VAT & $\begin{array}{l}\text { Hypothetic } \\
\text { Customs Value }\end{array}$ & $\begin{array}{l}\text { Real Customs } \\
\text { Revenue }\end{array}$ & $\begin{array}{l}\text { Revenue } \\
\text { difference }\end{array}$ \\
\hline Turqi & $77,643,472$ & $3,247,787$ & $3,386,459$ & $84,277,718$ & $0 \%$ & $20 \%$ & $16,855,544$ & $18,034,795$ & $1,179,251$ \\
\hline Kine & $39,466,180$ & $9,027,428$ & $73,673,120$ & $122,166,728$ & $0 \%$ & $20 \%$ & $24,433,346$ & $28,509,528$ & $4,076,183$ \\
\hline Itali & $3,745,173$ & - & $8,890,653$ & $12,635,826$ & $0 \%$ & $20 \%$ & $2,527,165$ & $6,362,482$ & $3,835,317$ \\
\hline Greqi & 156,285 & - & 5,114 & 161,399 & $0 \%$ & $20 \%$ & 32,280 & 135,737 & 103,458 \\
\hline Spanje & $6,846,612$ & - & - & $6,846,612$ & $0 \%$ & $20 \%$ & $1,369,322$ & $1,369,322$ & - \\
\hline Siri & $7,449,686$ & - & - & $7,449,686$ & $0 \%$ & $20 \%$ & $1,489,937$ & $1,489,937$ & - \\
\hline AE & - & - & $8,002,644$ & $8,002,644$ & $0 \%$ & $20 \%$ & $1,600,529$ & $2,357,716$ & 757,187 \\
\hline TOTAL & $\mathbf{1 3 5 , 3 0 7 , 4 0 8}$ & $\mathbf{1 2 , 2 7 5 , 2 1 5}$ & $\mathbf{9 3 , 9 5 7 , 9 9 0}$ & $\mathbf{2 4 1 , 5 4 0 , 6 1 3}$ & $\mathbf{0 \%}$ & $\mathbf{2 0} \%$ & $\mathbf{4 8 , 3 0 8 , 1 2 3}$ & $\mathbf{5 8 , 2 5 9 , 5 1 8}$ & $\mathbf{9 , 9 5 1 , 3 9 6}$ \\
\hline
\end{tabular}

\section{Summary and Recommendations}

The collection of revenue remains a top priority for many customs administrations, particularly in economies where a substantial portion of government revenue is derived from customs duties. A modern customs administration needs to apply the relevant tools and instruments- developed by the WCO and other international bodies - in a consistent manner in order to achieve fair, efficient, and effective revenue collection. Albania customs administration does not have any problem with harmonization of the rules as the methods of customs valuation for customs purposes is in accordance with Article VII of the General Agreement on Tariffs and Trade.

So our first recommendation is that the harmonized rules and recommendations surrounding customs valuation should, to the extent possible, be applied. The harmonized rules and recommendations have started at an international level such as the OECD, the World Customs Organization (WCO) and the EC. The biggest challenge for Albanian Customs is to apply them. We know that this is not something that can be done in one day as it is a whole process. Albania customs administration has all the possibilities to verify the invoices from EU countries and it doesn't make sense to use the last methods of customs valuation over products with EU origins without respecting the hierarchic aspect of the methods.

For all companies having cross-border transactions we recommend to establish a transfer pricing documentation for their business. For those companies also affected by customs regulations, it is recommended to take important customs issues into account, which may arise as a consequence of their transfer pricing policy. Importing companies should implement a price review clause in their contract before the importation and declare an incomplete declaration. It is also advisable to document the process of arising at a customs value. The trade community also has some tools at their disposal in this matter. It is important to plan ahead in respect of customs issues, to prepare contracts and commercial documentation taking into account possible contingencies that might arise regarding the determination of the customs value, to prepare detailed price formulas and, when available, to apply for a deferment of the final determination of the customs value.

To conclude we say that there is a need for an inter-institutional collaboration and a partnership in practice with the business. It makes no sense that the transaction value is sometimes accepted and sometimes even small interventions are made on it. All this except the financial implications clearly shows the lack of partnership in practice which is so much mentioned in these times. It is not important to knit postulates for the partnership, or even make worthless discussions and debates, the business really needs it. Said this we understand that we are more secure on the path of the integration walk when we see and treat business as a partner.

\section{References}

Ashiku, M. (2010). Financat Publike. Elbasan: Pegi.

DPD, D. e. (2013). Nomenklatura e mallrave. Tirane: DPD.

Elmazi, L. (2010). Kerkimi marketing. In L. Elmazi, Kerkimi marketing (p. 320). Tirana: Pegi. 
Kodi Doganor i Republikes se Shqiperise. In Ligji.

Rosen\&Gayer. (2010). Finance Publike. Tirane, Albania: UET Press.

WCO. (2007). EC Customs Code Reg 2913/92. Brussels: European Commision.

WCO. (December 2009). Revenue Management Conference . Brussel: WCO.

WCO. (2013, December 12). What is customs valuation. Retrieved 2013, from World Customs Organization: www.wcoomd.org

WTO. (2010). A Handbook on WTO Customs Valuation Agreemnts. Cambridge: Cambridge University Press.

WTO. (1994). General Agreements on Tariffs and Trade. Brussel: WTO.

WTO. (2013). Trade Raport. Brussel: WTO. 